\section{Ordforklaringer}

Inflammatorisk tarmsykdom (IBD): En gruppe sykdommer som forårsaker betennelse i tarmen og i noen tilfeller også $i$ andre organer i magen. De vanligste sykdommene er Crohns sykdom og ulcerøs kolitt.

Multifokal tykktarmskreft: Kjennetegnes ved multiple svulster eller forløperlesjoner til kreft i tarmen

Fokal tykktarmskreft: Kjennetegnes ved at ondartede slimhinneforandringer er begrenset til kun ett segment av tykktarmen.

EPJ: Elektronisk pasientjournal.

Se oversikt over doktoravhandlinger i seksjonen Oss imellom på side 1192

\title{
Får kreft tidligere enn antatt
}

\author{
Pasienter med inflammatorisk tarmsykdom har økt risiko for tykk- \\ tarmskreft etter ti år, men mange får kreft tidligere.
}

Forekomsten av inflammatorisk tarmsykdom i Norge er blant de høyeste i verden. Disse pasientene har økt risiko for tykktarmskreft, og den øker for hvert år etter at diagnosen er stilt.

- Tidligere har man trodd at kreftrisikoen oppstår minst ti år etter sykdomsdebut, og det er da man har startet regelmessig screening. Men våre funn viser at en overraskende høy andel utvikler kreft før det er gått ti år. Pasienter som får stilt diagnosen

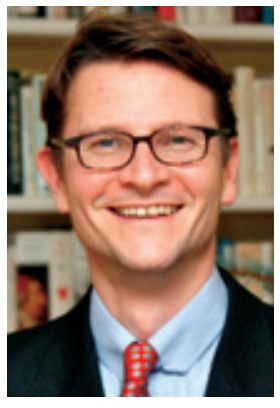

Stephan Brackmann. Foto privat i voksen alder er mer utsatt enn de som får diagnosen som barn, sier Stephan Brackmann.

I avhandlingen Colorectal cancer and IBD in Norway - a retrospective analysis er 67 pasienter med inflammatorisk tarmsykdom og tykktarmskreft inkludert. $12 \%$ av pasientene fikk kreftdiagnosen under ti år etter at de fikk symptomer på inflammatorisk tarmsykdom, mens $21 \%$ fikk kreftdiagnosen under ti år etter at diagnosen ble stilt.

En av studiene viser også at pasientene som får inflammatorisk tarmsykdom sent, i større grad rammes av fokal (lokalisert) tykktarmskreft. Pasientene som fikk diagnosen multifokal tykktarmskreft, var unge da de fikk påvist inflammatorisk tarmsykdom og hadde forholdsvis lang sykdomsvarighet før det oppsto kreft.

- Resultatene viser at vi må passe bedre på pasienter som får diagnosen inflammatorisk tarmsykdom i høy alder. De făr en krefttype som er vanskeligere å oppdage, og den oppstår tidligere enn antatt, sier Brackmann.

Han disputerte for ph.d.-graden ved Universitetet i Oslo 17.4. 2009.

\section{Eline Feiring}

eline.feiring@legeforeningen.no

Tidsskriftet

\section{Ja til elektronisk pasientjournal}

\author{
Allmennleger i Norge foretrekker den elektroniske pasientjour- \\ nalen og mener den gjør arbeidet lettere og gir bedre kvalitet. \\ Men de ønsker forbedringer på flere områder.
}

Dette viser Tom Christensen i avhandlingen Bringing the GP to the forefront of EPR development. Avhandlingen bygger på en nasjonal spørreundersøkelse, fokusgruppeintervjuer med allmennpraktikere og observasjonsstudier.

- I spørreskjemastudien undersøkte vi hvordan elektronisk pasientjournal ble brukt ved gjennomføring av 24 forskjellige kliniske oppgaver, brukertilfredshet og hvordan kvaliteten ved arbeidet påvirkes. Vi sammenliknet også funnene med en tilsvarende undersøkelse blant sykehusleger. Deltakerne

i fokusgruppene diskuterte positive og negative sider ved elektronisk pasientjournal og hva slags forbedringer de ønsker seg. I observasjonsstudiene registrerte vi hvordan journalen ble brukt, sier Christensen.

Studien viser at legene er fornøyd med elektronisk pasientjournal og at den gir god støtte til de kliniske oppgavene. Men det kom flere forslag til forbedringer: Den bør inneholde systemer for beslutningsstøtte som kan tilpasses den enkelte pasient, og all kommunikasjon bør kunne skje elektronisk, herunder kollegial rådgivning. Dessuten bør tilgangen til informasjon i store journaler bli bedre.

- Balansen mellom tid brukt på å snakke med og undersøke pasienten og tid brukt på å lese og dokumentere i systemet er viktig. Våre studier viser at bruk av elektronisk pasientjournal ikke forstyrrer lege-pasient-kontakten. Det er likevel viktig å undersøke hvordan det administrative arbeidet kan reduseres, sier Christensen.

Han disputerte for ph.d.-graden ved Norges teknisk-naturvitenskapelige universitet 19.3. 2009.

\section{Anne Forus}

anneforu@online.no

Tidsskriftet 